\title{
Folklore Motifs in Russian-Writing Yakut Literature (The Case of P. Chernykh-Yakutsky Works)
}

\author{
Elena Rufova ${ }^{1}$ \\ ${ }^{1}$ North-Eastern Federal University, Yakutsk, Russian Federation \\ Correspondence: Elena Rufova, Ridzinskogo 18/12, kv. 63, Yakutsk city, Republic of Sakha (Yakutia), 677005, \\ Russian Federation. Tel: 79-64-422-7755. E-mail: rufl2003@yandex.ru
}

Received: May 27, 2015 Accepted: July 16, 2015 Online Published: August 18, 2015

doi:10.5539/ass.v11n22p203 URL: http://dx.doi.org/10.5539/ass.v11n22p203

\begin{abstract}
All national literatures tend to draw on folk images, plots, symbols, and artistic means. Poems by P.Chernykh-Yakutsky differs from traditional Russian prose due to the fact that he is Yakut, but writes in Russian. Our research on his artistic style reveals ethnic originality, describes national peculiarities of images in the context of cultural concept. Using the case of P. Chernykh-Yakutsky works, the article analyses the relationship between folklore and literature in Yakut Russian-writing literature in the first third of the 20th century.
\end{abstract}

Keywords: national literature, folklore motif, Yakut literature, symbols, folklore and literature, Yakut Russian-writing literature, poems, folk images, symbols, artistic means

\section{Introduction}

Over the years, several scholars wrote on the relationship between folklore and literature (Medrish, 1980; Lotman, 1987; Toporov, 1995). Numerous researchers of national literatures also have studied the isuue: Sh. Eleukov (Kazakh literature), U. Kasybekov (Kyrgyz literature), S. Garmaeva (Buryat literature), R. Ukrasina (Bashkir literature), H. Bashirov (Azerbaijan literature) and others. As for the Yakut literature, various aspects of the relationship between literature and folklore have been covered in works by folklorists and literary critics who studied the history of Yakut literature.

The high artistic organizational structure of proverbs was in focus of such researchers as V. M. Zhirmunsky, N. N. Toburokov, M. N. Diachkovskaya, who emphasized organizational signs of the poetic speech. I. A. Khudyakov, V. L. Seroshevsky, and E. K. Pekarsky noted the value and originality of small genres of Yakut folklore in their ethnographic and linguistic materials. Another most ancient source of fiction is riddles, in their artistic structure more organized than proverbs. S. P. Oyunskaya's research revealed the imaginative reflection of the world in riddles. Other powerful layers of folklore, having organically merged with Yakut literature, are ritual poetry (G. U. Ergis) and folk songs (S. D. Mukhopleva). In the second half of the $19^{\text {th }}$ century, the genre of epic poetic pieces, toyuks, stood out in the folk poetry; they preceded the modern genre of poem, as N. N. Toburokov says. According to I. V. Pukhov, fairy tales, legends and stories played a significant role in the occurrence and development of prose in Yakut literature. Yet, the crown of Yakut folklore is, undoubtedly, olonkho, which absorbed all the varieties of Sakha folklore genres. According to famous scholar N. V. Yemelyanov, olonkho is rich in various plots, and shows the composition developing techniques typical of works of art.

In its development, Yakut literature went a long way, from the oral traditions of figurative reflection of reality and the human inner world to the first monuments of Yakut written literature - Memories by A. Ya. Uvarovsky and the olonkho tale by M. Androsova-Ionova in the second half of the 19th century. The artistic heritage of M. N. Androsova, a folk singer and a good connoisseur of folklore, has an interesting work Kyulkyul Bege and Silirikeen Old Woman created in 1893-1894, but published only in 1911. Inspired by olonkho and written in the olonkho style, it is, in fact, a work of literature, reflecting the real life of the characters and their relationships, taking its rightful place among the significant monuments of the literature. These two major works, the first written records of Yakut literature represent historical attempts to create individual works of literature. Thus, the research of the scholars and the first literary monuments prove that Yakut literature followed the universal pattern in the history of other literatures of the world - it started with the evolution of folklore genres and forms. 


\section{Method}

Yakut literature was influenced by another factor - historical events in Russia in the late 19th - early 20th century, which stirred up the public consciousness of the peoples of Yakutia, had a positive impact on the consciousness of the people, on wakening their dignity and self-esteem. At this moment of transition, at the intersection of historical epochs, national cultures and languages, there appeared a new trend in the Yakut literature - Yakut Russian-writing literature. The early $20^{\text {th }}$ century was to become a significant milestone not only for the development of relations between Russia and Yakutia, but also for the convergence of Russian and Yakut people, largely through Russian literature. The beginning of the $20^{\text {th }}$ century, as the time for the Russian-language literature appearance in Yakutia, was a difficult period, given the fact that the beginning of the century was a time for the political change of eras and ideals, the time to search for political, social, and spiritual values, as well as means of artistic expression. The drama of that time, according to N. S. Nadyarnykh, is explained by the very specific nature of the written literature genesis. There took place a clash of two types of artistic consciousness, two ways of expressing the meaning merge and interact: the oral word and the written word. With young literatures, and it is the case of the Yakut literature in the beginning of the 20th century, there is another serious problem - "the problem of the context of literature, or, in other words, the problem of relating the national "text" of literature with all its contents and forms, as well as with its context - historical, cultural, and social." One of the founders of the Yakut Russian-writing literature was poet Petr Nikodimovich Chernykh (1882-1933), born in a mixed marriage, who was fluent in both Russian and Yakut languages and knew Yakut folklore and works of Russian classical writers. The poet himself wrote mostly in Russian, although some of his poems were written in Yakut. Besides, P. N. Chernykh is also known as one of the first translators The Red Shaman, a poem by the founder of Yakut Soviet literature P. A. Oyunsky, who approved the translation. Fruitful cooperation with the political exiles, work for the local press, a personal meeting with writer Maxim Gorky - all this characterizes P. N. Chernykh-Yakutsky as an active local poet who made a significant contribution to the development of the literary process of Yakutia in the early $20^{\text {th }}$ century.

\section{Results}

P. Chernykh published a more mature work in the Yakut press after the revolution of 1905. It was a small poem in prose "The sounds of the weather", published under the pseudonym Yuri Fioletov in The Yakutsky Krai newspaper on August 30, 1907. It is remarkable by its interpretation of folk images. Under the howling wind and blowing snow, in the light of the fireplace in a yurt, an old man tells an old Yakut legend, and his speech flows like a broad river. It is full of poetry, it takes the audience away to the distant and bizarre world of fairy tales and wonders: "... in the early morning, there is a clash between two heroes: the Black Warrior- the Knight of Death, a hater of the light and joy, and the White Warrior - the defender of the light and good. They are fighting fiercely. The White Warrior, defending the light and good, is having a difficult time, but being mighty and just, he will win the enemy..." Using the images of the Yakut heroic epic, the writer, who thought highly of Yakut folklore, depicts the world of cruelty in the image of the Black Warrior and the world of justice and love in the image of the White Warrior.

For highlighting of certain images in contrast to the general background, the following compositional techniques can be useful to some extent: repetition, "focusing", "assemblage" and retardation. Through repetition a detail gains additional meaning, becoming a motif (leitmotiv), and often assumes a symbolic form. By selecting and inventing various details, the writer is able to delivers story's content to the reader from a particular angle. Thus, nature as a descriptive detail described by P. Chernykh-Yakutsky in his works above all is a "participant" in the transpiring. In his first published work "The sound of the weather" he uses the image of wind as a harbinger of change and hope. But the wind, being a "mournful cry" of the North snowstorm, a restless blizzard, is a symbolic personification of the battle between two heroes - a white warrior and a black warrior. Freezing in anticipation is the effect that this depiction is hoped to produce on the reader when the warriors engage in a battle while outside the window the "snowstorm moans and cries, menacing of something grave and hateful, scratching with its frosty claws at the squeaky door...". And even the death of the black warrior is pictured by the author as a natural phenomenon - the "warrior's heart gave out; it trembled like a leaf under the furious North wind". And already one can feel "in the wind's bold and vigorous gusts a call for something bright, vigorous and joyful".

In all of the Chernykh-Yakutsky's works one can see the image of the kamelek, Yakut traditional oven. This symbolic detail is used by the author as a symbol of family, people and nation unity. This instrument of daily life is of vital significance for the Yakut people both as a means of survival, given the severe climatic conditions, and a center of human activity where people cooked, greeted the guests and talked about their lives. In the story "In the Taiga" the "crackling fireside" is used by the author as a symbol of Yakut family and home is juxtaposed with the "moist air of the rarely heated church" as a contrast of two cultures, two religions and two worlds of the hero 
- the old and the new - Shamanism and Christianity.

The degree of image, especially the outside world, can be motivated in the text by a particular narrative place (defined in the spatial or temporal coordinates), or otherwise by the spatial and/or temporal point of view of the narrator. Thus, a yurt in scenery description is a commonly found subject detail in the works of P. Chernykh-Yakutsky. The yurt is presented as a certain closed, delimited space in opposition to the wide and vast nature. Its mundane, ordinary and gray interior is contrasted with the beautiful, rich and bright nature. When the hero of the "In the Taiga" story looks around the boundless expanse of his native country "Sakha people's grayish yurts" are seen in the background. The yurt is also depicted as a kind of a "social club", a gathering place for regular listeners, usually ulus (village) youth, who are stylistically highlighted against the "elders who are less enthusiastic to come to the yurt." In the story, "From the Recent Past" we can see "grayish yurts, coated with cow dung, all gathered together near mirror-like lakes" represents a kind of a vacuum, an inner world without unnecessary things and people, shielded from the hostile winter environment outside. These particulars, the images of everyday life of the Sakha people arises in the P. Chernykh-Yakutsky's works to evoke images in the minds of readers of the unique world of the Yakut ulus and the lives of its inhabitants, the contemporaries of the author.

The life of the representatives of an ethnic group is expressed in their ethnically-specific forms of behavior which is usually an implicit or unconscious set of behaviors. The inner world of literary characters is revealed most effectively in terms of the compliance of the character's behavior and personal attitudes with the rules of the society. Thus, the rules of the Yakut society grew out of the experience of a constant threat from the outside world which naturally led to the incessant need to protect oneself, one's family, clan and tribe. In this regard, it is informative that the inner world of P. Chernykh-Yakutsky's characters is filled with sustained anxiety, distrust and sometimes even the denial that the source of it are the "outside" influences. This internal state of the characters intensifies the psychological impact of the work, and through the use of psychological details the author is able to deepen the description of the characters. Thus, the author clearly exposes his point of view through the choice of artistic details and makes apparent his preference of modality, pragmatics, and systematics.

In the surviving manuscripts of the poet, one can find his notes on the inexhaustible power of the Yakut poetic language: "How poor and plain the vocabulary of the Yakut everyday speech is, and how rich, colorful and varied is the language of the Yakut poetry. Brilliant metaphors, apt similes, bold likening make the Yakut poetic language utterly expressive." There are also lines so vividly describing the reverent attitude of the author to the masterpieces of the Yakut epic "... Olonkho is the arena where the Yakut mythological and religious characters live and act. Olonkho is the Yakut Olympus, where the Yakut gods live along with the warriors and shamans." Growing up with Yakut traditions and the best examples of Yakut folklore, P. N. Chernykh-Yakutsky repeatedly turned to them in his work, praising the beauty of the nature and the native land.

\section{Discussion}

The national originality of P. N. Chernykh-Yakutsky's works is manifested in the way of creating images, vocabulary chosen, use of indirect forms of folk motifs, the manner of depicting the natural scenery. In his works, P. N. Chernykh-Yakutsky felt intuitively the tragic gap between man and nature. He never used nature as a background of the action; it was an independent, highly emotional part of it, which explaines his love for the Romantic landscape. He often opposed natural phenomena: the sunbeam, the storm and bad weather, expressing through them all his concern and pain for what was happening around. There came a need for the deification of nature, sometimes tender as a mother, then mysterious, frightening, or hostile. Nature called upon man to stop, to reflect and do something immediately to change the social reality. The peculiarity of the poet's individual style is not so much in the actual depiction of nature, but rather in the particular national vision of the author, in unique collaboration and harmony of the images, shades of colours that best meet the aesthetic objectives set by the poet.

The last written work of P. N. Chernykh-Yakutsky is an excerpt from Khaan Jargystai olonkho, which was published after his death in 1945. In this work, the author aimed at acquainting the public with Yakut literature; moreover, the images inspired by the Yakut national epic accompanied the poet throughout his life. From the first publication to the last of his creative works, P. N. Chernykh-Yakutsky had indissoluble connection with images of Yakut folklore.

Writing his works in Russian, P. Chernykh-Yakutsky (a native Yakut) expresses through it above all a national world, a centuries-old experience of people and therefore in his creative works emerges a nationally characterized world view. Originality and ethnic peculiarities of artistic details constitute his style, which gives the reader the opportunity to go beyond the text and paint the literary picture for himself. 


\section{Conclusion}

The issue of the relationship between folklore and literature contains the issues of the correlation between two ideologies, two artistic methods, and two systems. The initial period of the Yakut literature, as a whole, can be referred to as a period of "direct" borrowing of folk traditions, the beginning of poetry and small-form prose. Writers sought to convey swift-change in the society to the reader in the traditional form, for example, in the form of stories, using images of the native folklore - warriors, shamans, and others.

In general, the analysis of P. N. Chernykh-Yakutsky's creative heritage reveals the national identity of his works, which is particularly manifested in his pastoral poetry and prose, where the category of the national is reflected in the use of folklore motifs, images, and symbols, closely related to the peculiarities of the national mentality.

Descriptiveness is the dominant element in P. Chernykh-Yakutsky's style, as the descriptive details are the dominant artistic detail of his style of writing. As a Yakut, he has a keen sense of observation and good an understanding of nature, beauty and the glorious which permits him to delicately express diverse moods of nature. In the majority of his works he creates an image of Yakutia in the form of landscape sketches in the style of XIX century Russian Romanticism. But the presence of Spring as a poetic symbol in almost every one of his works gives his literary style a special ethnic uniqueness. He awaits "when a beautiful taiga spring from the South will come, shrouded in colorful flower wreaths, fanned with tender scents"; he sings the Spring as the traditional Sakha songs are usually sung: "a white silk of sparkling Yakut night is stretched above the taiga, bright as the day, marvelous as the tale". His system of various artistic details is also original: metaphors with a national subtext, metaphoric comparisons, an inclination to use detailed epithets, and the preference to use paired words and expressions, reflective of the melodic consonance of the Yakut national verse. Every part of his writings is permeated with the spirit of national aesthetics, with a striving to glorify not only by words, but also by the sounds, expressing his own vision of the world through the pictures of nature. Thus, Chernykh-Yakutsky's sun is always gold, the stars are always like diamonds, and the water in the lakes looks like "liquid gold". Numerous repetitions, imbued with the poetic image of Yakutia, also stresses the national significance of the writer's prose.

\section{Acknowledgements}

The paper has been prepared within the Research Project 13-34-01253 approved by RFH.

\section{References}

Chernyh-Yakutsky, P. N. (1982). My Motherland Yakutia: The Poems, Stories and Essays. Yakutsk: Yakut Publishing House.

Diachkovskaya, M. N. (1998). Alliteration and rhyme in poetry Yakut. Problems of evolution and classification. Novosibirsk: SB RAS SIC UIGGM.

Ergis, G. U. (1974). Essays on folklore Yakut. Moscow: Nauka.

Khudyakov, I. A. (1969). Brief description of the Verkhoyansk District. Leningrad: Nauka.

Lotman, Yu. M. (1987). Symbol in the culture. Tartu.

Medrish, D. N. (1980). Literature and folklore tradition. Saratov.

Mukhopleva, S. D. (1993). Yakut folk ritual songs. The system of genres. Novosibirsk.

Nadyarnykh, N. S. (2008). Axiology rereading. Moscow: Institute of World Literature of the RAS.

Oyunskaya, S. P. (1992). Yakut folk riddles. The specifics of the genre. St.Petersburg.

Pekarsky, E. K. (1905). Brief Russian-Sakha dictionary. Published in the means of Yakut Regional Statistics Committee. Yakutsk.

Pukhov, I. V. (1962). Yakut heroic epic. Key images. Moscow: Nauka.

Seroshevsky, V. L. (1993). Yakutia. The experience of ethnographic research. Moscow.

Toburokov, N. N. (1992). Siberia born: an essay on poetry peoples of Siberia. Yakutsk: Bk. Publishing House.

Toporov, V. N. (1995). Ritual. Symbol. Image. Research on the mythological. Moscow. http://dx.doi.org/ $10.1515 / 9783110935738$

Yemelyanov, N. V. (1983). Topics of the early types olonkho. Moscow: Nauka.

Zhirmunsky, V. M. (1979). Comparative Literature: East and West. Leningrad: Nauka. 


\section{Copyrights}

Copyright for this article is retained by the author(s), with first publication rights granted to the journal.

This is an open-access article distributed under the terms and conditions of the Creative Commons Attribution license (http://creativecommons.org/licenses/by/3.0/). 